\title{
Landslide Hazards and Climate Change Adaptation of Transport Infrastructures in Germany
}

\author{
Martin Klose, Markus Auerbach, Carina Herrmann, Christine Kumerics, \\ and Annegret Gratzki
}

\begin{abstract}
This paper provides insights into a new landslide hazards project which is part of a national research program on safe and sustainable transport in Germany funded by the Federal Ministry of Transport and Digital Infrastructure (BMVI). Here we report on a work in progress and present selected results of a pilot study conducted prior to the launch of the research program in 2016. The main goal of the landslide hazards project is to assess the future landslide hazard potential for the federal transport system under the influence of climate change. A federal road-related pilot study with focus on developing an approach to this type of hazard assessment was a first step in this direction. The developed approach is based upon a Geographic Information System (GIS) as mapping tool to combine a landslide susceptibility map with spatial datasets of regional climate change projections. Here we present the basic framework of this approach only, and provide information on landslide activity and climate change. This information refers to findings from three example landslide sites in Germany. The purpose of this paper is to introduce these landslide projects of German transport research against the backdrop of the existing national strategy of climate change adaptation.
\end{abstract}

\section{Keywords}

Landslide hazards - Transport infrastructure - Climate change adaptation - Germany

M. Klose $(\bowtie) \cdot$ M. Auerbach

Federal Highway Research Institute (BASt), Brüderstraße 53, 51427 Bergisch Gladbach, Germany

e-mail: Klose@bast.de

M. Auerbach

e-mail: AuerbachM@bast.de

C. Herrmann

Federal Railway Authority (EBA), Heinemannstraße 6, 53175

Bonn, Germany

e-mail: HerrmannC@eba.bund.de

C. Kumerics

Landslide Research Centre at the Johannes Gutenberg-University

Mainz, Mombacher Straße 49-53, 55122 Mainz, Germany

e-mail: fsr@geo-international.info

\section{A. Gratzki}

German Meteorological Service (DWD), Frankfurter Straße 135, 63067 Offenbach, Germany

e-mail: Annegret.Gratzki@dwd.de

\section{Introduction}

The transport system of the Federal Republic of Germany is one of the densest and most developed transport systems of the world (Fig. 1). Being an essential part of the Trans-European Transport Network (TEN-T), it serves as a backbone of Germany's export economy and the European Union (EU) single market (e.g., European Commission, 2011). The resilience of transport systems in Germany and Europe depends to a large extent on the success of climate change adaptation (e.g., Nemry and Demirel 2012; Conference of European Directors of Roads 2013; European Environment Agency 2014). In order to lay the foundation for safe and sustainable transport in the 21st century, thousands of kilometers of road, waterway, and railroad infrastructure throughout the country need to undergo a scientific 


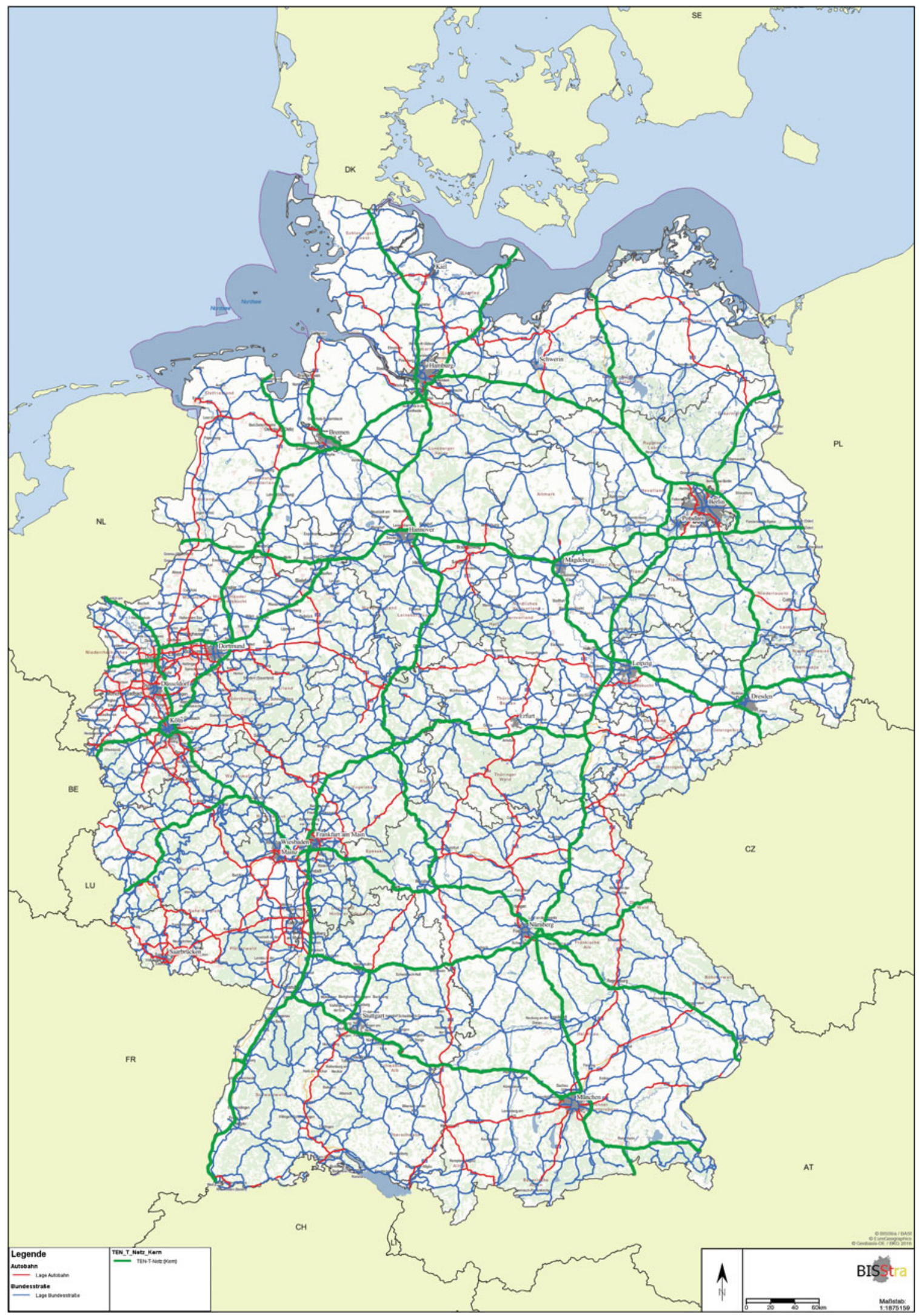

Fig. 1 The federal road network of Germany as one of the densest and most developed road networks of the world (red: Bundesautobahnen; blue: Bundesstraßen). This map also illustrates the core network (green) of the Trans-European Transport Network (TEN-T). Source BISStra 2016, Federal Highway Research Institute (BASt), CBISStra/BASt, CEuroGeographics, CGeobasis-DE/BKG 2016 
assessment of potential climate change impacts, both at the system and object level. The criterion of climate change policy in Germany is the German Strategy for Adaptation to Climate Change (The Federal Government 2008; Federal Ministry for the Environment, Nature Conservation and Nuclear Safety 2012; Die Bundesregierung 2015). This strategy applies to the whole public sector, including transport and infrastructure, and constitutes a legal basis for putting science and strategy into practice.

Climate change adaptation requires assessing climate change impacts (e.g., Noble et al. 2014). It is due to their dependency on rainfall extremes and anomalies that landslides serve as an example for climate change impacts on roads worldwide (e.g., World Road Association 2015). The German transport system, and especially road transport, is recognized to be affected by landslide damages, both direct and indirect (e.g., Keller and Atzl 2014; Klose et al. 2015; Fig. 2). Information on the exposure and vulnerability to and the potential impact of these damages provide a first basis for scientific approaches to safe and effective road operations under the influence of climate change. As elsewhere in Europe (e.g., Spizzichino et al. 2010), landslides affecting roads in Germany are usually local, but widespread phenomena, interacting with rainfall extremes and anomalies over time (e.g., Krauter et al. 2012). Climate change adaptation in the sense of landslide risk reduction is a challenging task as being confronted with these complex interactions and their direct implications on risk assessment and management.

This paper reports on research activities in the field of climate change adaptation by using the example of landslide hazards and transport infrastructures in Germany. Here we present a new landslide hazards project which contributes as work in progress to the current strategic and scientific efforts for enabling effective climate change adaptation, either at national or international level. This is followed by a summary of selected results of a pilot study conducted before the beginning of the new landslide hazards project in 2016.

\section{Research Program}

\section{Overview}

The topic of landslide hazards represents the central theme of a project within a national research program of the Federal Ministry of Transport and Digital Infrastructure (BMVI). This new research program currently funds three research fields consisting of several individual projects each (http://www. bmvi-expertennetzwerk.de). One of the main goals across these research fields is to address the challenges related to climate change and safe and sustainable transport through collaborative research following an interdisciplinary approach bringing together scientists and practitioners from research fields such as climatology, civil engineering, and geosciences. The participating research institutes and agencies include the Federal Highway Research Institute (BASt), the German Meteorological Service (DWD), the Federal Railway Authority (EBA), the German Federal Institute of Hydrology (BfG), the Federal Waterways Engineering and Research Institute (BAW), the Federal Maritime and Hydrographic Agency (BSH), and the Federal Office for Goods Transport (BAG). This network of research institutes and agencies operates at the interface between science and practice, with the goal of providing effective knowledge transfer and advice for decision makers in government and industry. Research and development aims at implementing scientific solutions and best practices for climate change adaptation and sustainable development of the federal transport system of Germany.

\section{Landslide Hazards}

The landslide hazards project contributes to a research field addressing the topic of adaptation to climate change and extreme weather events. High priority within this research field is given to hazard and risk assessments for different modes of transport (road, rail, water) and various types of climatic extremes or secondary geologic hazards. The main goal of the landslide hazards project is to evaluate both the current exposure of federal transport routes to landslides and the future landslide hazard potential under the influence of climate change. In order to reach this goal and to make data products available for national hazard and risk assessments in Germany, it is intended to apply and combine existing and new methods, including landslide inventory, hazard mapping, as well as impact and vulnerability assessment. The research and innovation approach of this project covers the risk assessment cycle and is characterized by four main steps:

(1) Landslide identification and inventory. Information about historical and current landslide events and the resulting damages is critical for hazard and risk assessment. The goal therefore is to develop and maintain a landslide inventory for the federal transport system of Germany.

(2) Landslide hazard mapping. A key to best practices in planning and maintenance are landslide hazard maps that take account of the potential influence of climate change. It is intended to optimize methods enabling to combine landslide susceptibility maps with regional climate change projections.

(3) Landslide impact and vulnerability assessment. Landslide risk is generally understood as a function of exposure and vulnerability. In order to improve resilience through effective risk assessment, potential impacts and vulnerability will be investigated, both at the object and network level. 


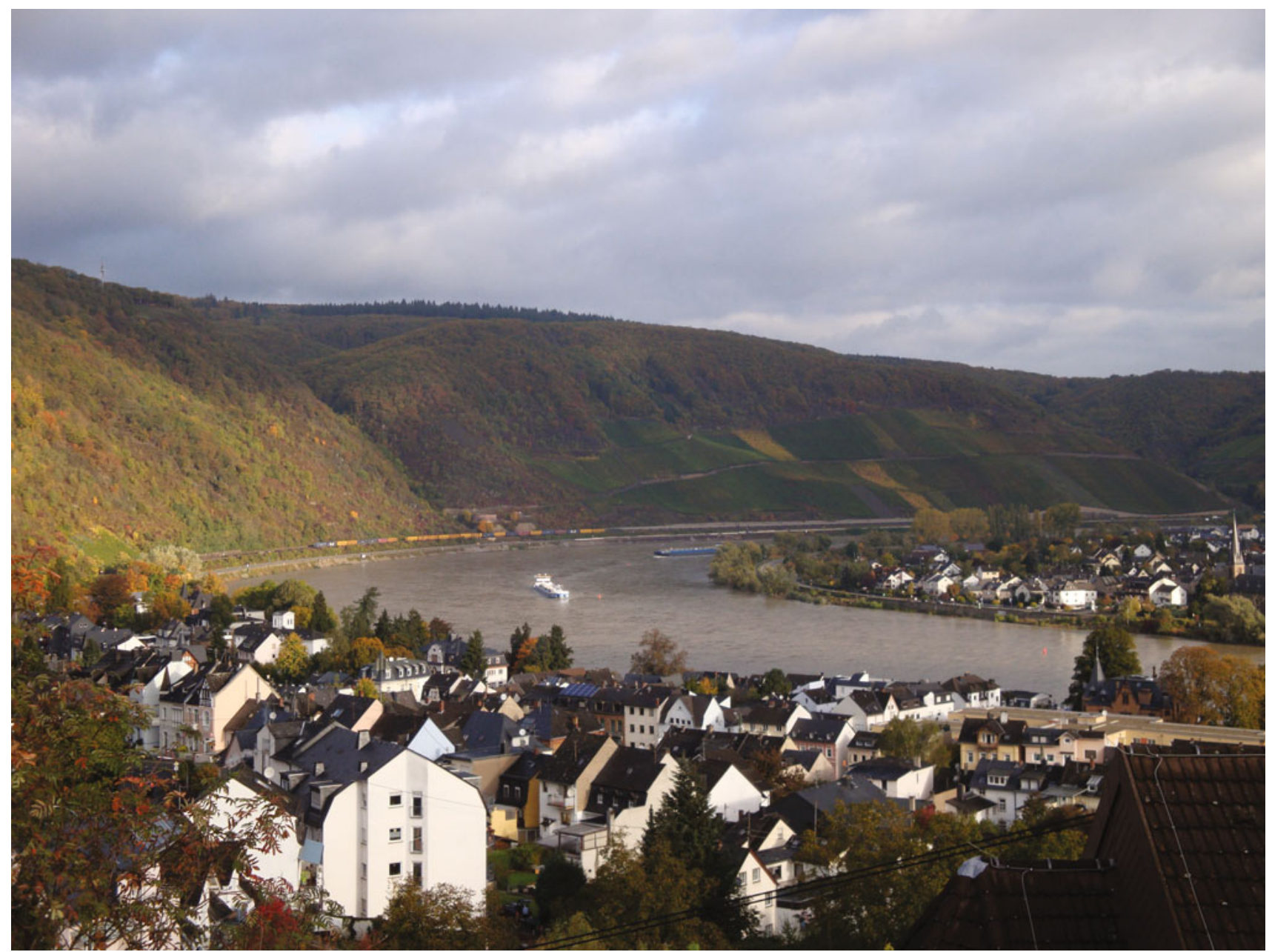

Fig. 2 The Upper Middle Rhine Valley, southwest Germany - a transport corridor of trans-European economic importance. As a natural transit route for road, rail, and water transport passing through the Rhenish Slate Mountains, this deeply incised river valley is characterized by a spatial concentration of critical transport infrastructures, with some of which being located in areas prone to landslides and related types of hazards (Photo M. Klose, BASt)

(4) Hazard communication. Research and development to the benefit of climate change adaptation requires policy guidance and knowledge transfer to practitioners. This should be realized by making use of innovative geospatial and web mapping technologies.

\section{Pilot Study}

\section{Background}

The following sections present a pilot study conducted prior to the landslide hazards project of the national research program. Here it is referred to a specific road-related landslide study now serving as an ideal starting point for this new project. The goal of the pilot study was to develop a method to assess the future landslide hazard potential along the
German federal road network. Two research projects in the context of the AdSVIS program (Auerbach et al. 2014) were therefore commissioned by the Federal Highway Research Institute (BASt) in the recent past. Further information on the specific goals and tasks of one of these projects is given in the report prepared by Krauter et al. (2012). In the following two sections, we report on some of the main outcomes of the pilot study, with special emphasis on data sources and the methodological approach.

\section{Method}

The key element of the method developed in this pilot study is a Geographic Information System (GIS). It serves as a mapping tool that provides GIS functionality to organize, analyze, and illustrate geospatial and climatic datasets. ESRI ArcGIS 10.1 was used as software to implement the method 
and its different components. The approach to hazard mapping consists of two specific models that in combination enable a GIS-based assessment of the future landslide hazard potential along federal road corridors throughout the country (Fig. 3). A heuristic landslide susceptibility model resting upon expert opinion in factor selection and classification specifies the current exposure to landslides on the basis of experiences about predisposing factors of historical and current landslides in Germany. Alternatively, two types of regional climate models (RCMs) provide projections for climate parameters acting as potential triggering factors of landslides on soil and rock slopes within a $500 \mathrm{~m}$ buffer at each side of the road corridors. Both parts of this method are embedded into a GIS tool that integrates and processes the input data by means of qualitative map combination as well as spatial data overlay and intersection (Fig. 3).
Fig. 3 Methodological approach to the assessment of the future landslide hazard potential along federal roads in Germany. The diagram also illustrates the data material necessary for the application of the different methods of this approach. Data material ${ }^{1}$ Federal Institute for Geosciences and Natural Resources $(B G R) ;{ }^{2}$ Federal Agency for Cartography and Geodesy $(B K G) ;{ }^{3}$ For model validation only, multiple sources; ${ }^{4}$ Federal Agency for Cartography and Geodesy $(B K G) ;{ }^{5}$ Federal Highway Research Institute $(B A S t) ;{ }^{6}$ International scientific consortium (http://www.clmcommunity.eu/; http://www2. cosmo-model.org/), German Meteorological Service ( $D W D)$; ${ }^{7}$ Max Planck Institute for Meteorology (MPI-M), German Meteorological Service $(D W D)$

\section{Landslide Susceptibility Model}

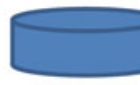

Geological

Overview Map ${ }^{1}$ (GÜK 200)<smiles>C1CC2CCC(C2)N1</smiles>

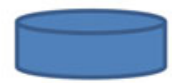

Digital Elevation Model $^{2}$ (DEM 10)

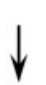

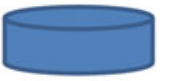

Landslide Inventory $\mathrm{Map}^{3}$

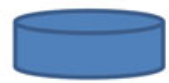

Digital Land(DLM 250)

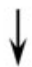
scape $\mathrm{Model}^{4}$
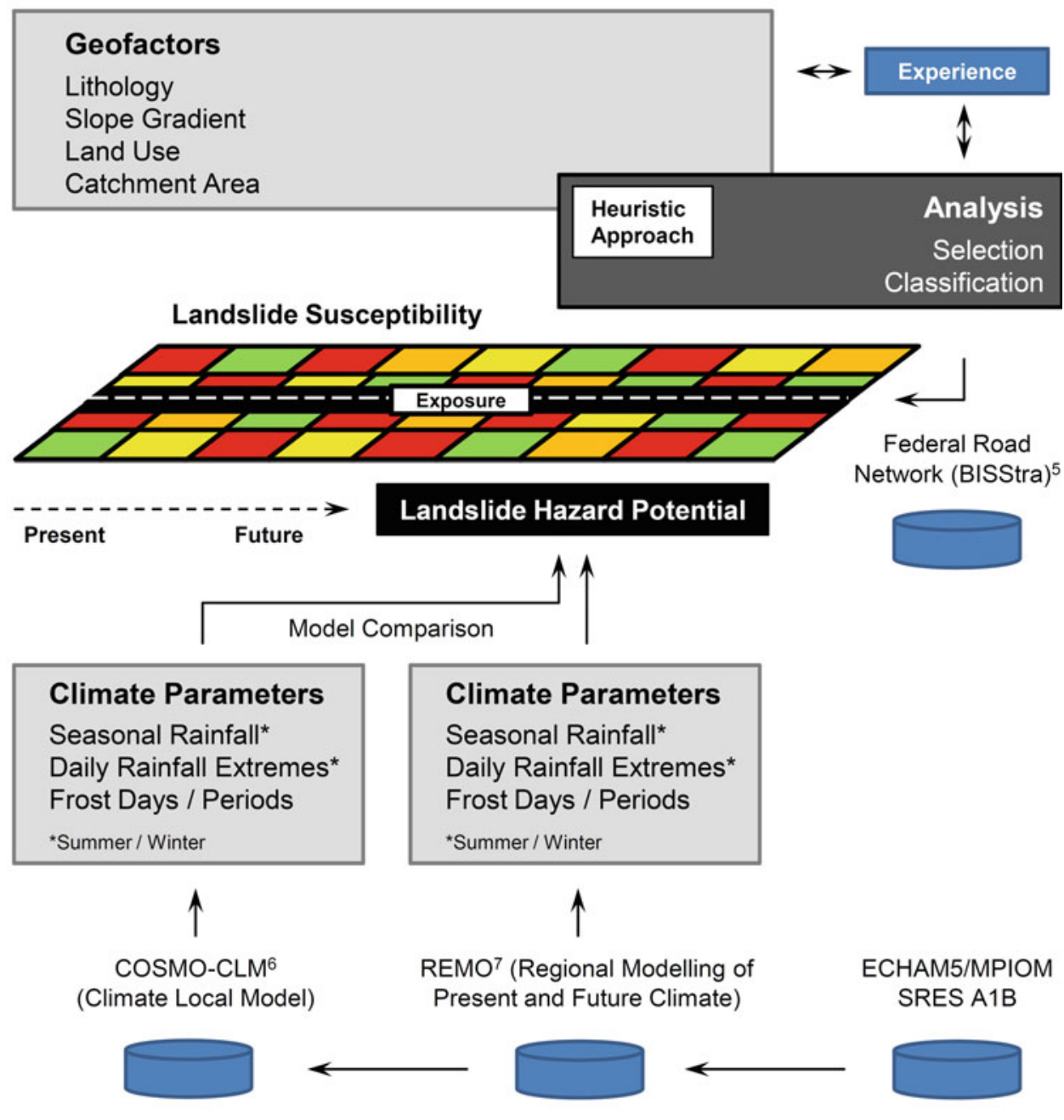


\section{Results}

The results of the pilot study and subsequent research activities are in part of preliminary character. This mainly applies to the hazard maps developed using the methodological approach illustrated in Fig. 3. Here it is therefore referred to the results discussed in Krauter et al. (2012) only. Using the example of three landslide sites in west and northwest Germany (see also Damm 2005), the historical relationship between rainfall, temperature, and landslide activity was reviewed and analyzed, with the goal of linking this analysis with datasets of climate projections in a qualitative way.

These datasets for different climatic parameters were derived from the regional climate model REMO (Regional Modelling of Present and Future Climate). REMO is a dynamical RCM based on the global climate model (GCM) ECHAM5/MPIOM. With a maximum spatial grid cell resolution of approximately $10 \mathrm{~km}$ for Germany, it provides datasets for climate parameters at an hourly and daily basis. In this pilot study, a set of climate parameters, including seasonal rainfall, daily rainfall extremes, frost days, and frost periods was used to assess the landslide influence of climate change for both summer (Apr-Sep) and winter (OctMar) on a 30 -year average until 2100. This influence is defined by the future parameter changes compared to the reference period 1971-2000, with seven future time intervals ranging from 2011-2040 to 2071-2100. The emission scenario (SRES) taken into account in this pilot study was the moderate SRES A1B scenario (Krauter et al. 2012).

For the three example landslide sites, the report indicates a future increase in daily rainfall extremes in summer, while the total summer rainfall is expected to decrease. In winter, by contrast, both total rainfall and daily rainfall extremes will potentially increase, which is accompanied by a decrease in the number of frost days and frost periods, as indicated by this report. Given the datasets on the historical influence of climate on landslide activity, the report suggests for both soil and rock slopes an increase in the future landslide hazard potential. This is due to a potential increase in shallow landsliding and debris flow activity in future summers as well as a potential increase in landslide and rockfall activity in future winters (Krauter et al. 2012).

\section{Conclusions}

The pilot study was a first attempt to assess the future landslide hazard potential along the German federal road network under the influence of climate change. Although some of its results are still of preliminary character, it now serves as an ideal starting point for further research and development in this context. The results will be incorporated into the ongoing landslide hazards project that started its work after the launch of the national research program at the beginning of 2016. This work in progress is focused, among others, on expanding the methods available, updating the climate modeling components, and integrating other modes of transports into the method as well. The knowledge base for this specific field of transport planning has significantly improved in recent times. Landslide inventories, hazard maps, and risk assessments along with innovative mapping or monitoring technologies are now playing an increasingly important role in landslide research globally (e.g., Guzzetti et al. 2012; Van Den Eeckhaut and Hervás 2012; Corominas et al. 2014). In order to translate this scientific progress into research and development at national level, the project aims at making use of the existing global knowledge base to meet the requirements of transport planning and policy within the country. The project contributes to the national research program in ways that enable reaching the overarching goal of safe and sustainable development of transport systems in Germany.

Acknowledgements This research work was funded by the Federal Ministry of Transport and Digital Infrastructure (BMVI). It is part of the BMVI-Expertennetzwerk Wissen-Können-Handeln. The funding of this national research program is gratefully acknowledged. The authors would like to thank Dipl.-Geol. Michael Bürger, Federal Highway Research Institute (BASt), for his personal advice and the supervision of previous research projects. The pilot study discussed in the paper refers to the projects FE 89.238/2009/AP and FE 05.0170/2011/MRB commissioned by the BASt. We very much appreciate the support received from all parties involved in the two projects. Special thanks are due to the Landslide Research Centre at the Johannes Gutenberg-University Mainz which conducted both projects on behalf of the BASt. We would also like to thank the different research institutes and agencies that provided data material for these projects. A detailed list of these research institutes and agencies is given in Fig. 3. The authors are grateful to Dipl.-Ing. Jens Kirsten, BASt, who supported the preparation of Fig. 1.

\section{References}

Auerbach M, Herrmann C, Krieger B, Mayer S (2014) Klimawandel und Straßenverkehrsinfrastruktur. Straße und Autobahn 7:531-539

Conference of European Directors of Roads (2013) Adaptation to climate change. CEDR report 2013/07. CEDR's Secretariat General. p 168. URL: http://www.cedr.fr/home/fileadmin/user_upload/Publications/ 2013/T16_Climate_change.pdf. Last accessed 25 Aug 2016

Corominas J, van Westen C, Frattini P, Cascini L, Malet J-P, Fotopoulou S, Catani F, Van Den Eeckhaut M, Mavrouli O, Agliardi F, Pitilakis K, Winter MG, Pastor M, Ferlisi S, Tofani V, Hervás J, Smith JT (2014) Recommendations for the quantitative analysis of landslide risk. Bull Eng Geol Env 73(2):209-263

Damm B (2005) Gravitative Massenbewegungen in Südniedersachsen. Die Altmündener Wand-Analyse und Bewertung eines Rutschungsstandortes. Zeitschrift für Geomorphologie NF, Suppl.-Bd. 138:189-209

Die Bundesregierung (2015) Fortschrittsbericht zur Deutschen Anpassungsstrategie an den Klimawandel. Stand: 16, November 2015. URL: http://www.bmub.bund.de/fileadmin/Daten_BMU/ Download_PDF/Klimaschutz/klimawandel_das_fortschrittsbericht bf.pdf. Last accessed 25 Aug 2016 
European Commission (2011) White paper. Roadmap to a single European transport area-towards a competitive and resource efficient transport system. URL: http://ec.europa.eu/transport/ themes/strategies/doc/2011_white_paper/white_paper_com\% 282011\%29_144_en.pdf. Last accessed 25 Aug 2016

European Environment Agency (2014) Adaptation of transport to climate change in Europe - challenges and options across transport modes and stakeholders. EEA Report 08/2014. Publications Office of the European Union, Luxembourg, p 60 (ISBN 978-92-9213-500-3)

Federal Ministry for the Environment, Nature Conservation and Nuclear Safety (2012) Adaptation Action Plan for the German Strategy for Adaptation to Climate Change. Federal Ministry for the Environment, Nature Conservation and Nuclear Safety (BMU), Public Relations Division, Berlin, Germany, p 79

Guzzetti F, Mondini AC, Cardinali M, Fiorucci F, Santangelo M, Chang K-T (2012) Landslide inventory maps: new tools for an old problem. Earth Sci Rev 112(1-2):42-66

Keller S, Atzl A (2014) Mapping natural hazard impacts on road infrastructure - the extreme precipitation in Baden-Württemberg, Germany, June 2013. Int J Disaster Risk Sci 5(3):227-241

Klose M, Damm B, Terhorst B (2015) Landslide cost modeling for transportation infrastructures: a methodological approach. Landslides 12(2):321-334

Krauter E, Kumerics C, Feuerbach J, Lauterbach M (2012) Abschätzung der Risiken von Hang- und Böschungsrutschungen durch die Zunahme von Extremwetterereignissen. Berichte der Bundesanstalt für Straßenwesen. Straßenbau, Heft S75. Wirtschaftsverlag NW, Bremerhaven, p 61

Nemry F, Demirel H (2012) Impacts of climate change on transport: a focus on road and rail transport infrastructures. JRC Scientific and Policy Reports. Report EUR 25553 EN. European Commission, Joint Research Centre, Institute for Prospective Technological
Studies. Publications Office of the European Union, Luxembourg, p 89 (ISBN 978-92-79-27037-6)

Noble IR, Huq S, Anokhin YA, Carmin J, Goudou D, Lansigan FP, Osman-Elasha B, Villamizar A (2014) Adaptation needs and options. In: Field CB, Barros VR, Dokken DJ, Mach KJ, Mastrandrea MD, Bilir TE, Chatterjee M, Ebi KL, Estrada YO, Genova RC, Girma B, Kissel ES, Levy AN, MacCracken S, Mastrandrea PR, White LL (eds) Climate change 2014: impacts, adaptation, and vulnerability. Part A: global and sectoral aspects. Contribution of Working Group II to the Fifth Assessment Report of the Intergovernmental Panel on Climate Change. Cambridge University Press, Cambridge, United Kingdom and New York, NY, USA, pp 833-868 Spizzichino D, Margottini C, Trigila A, Iadanza C, Linser S (2010) Chapter 9: landslides. In: European Environment Agency (ed) Mapping the impacts of natural hazards and technological accidents in Europe: an overview of the last decade. EEA Technical report 13/2010. European Environment Agency. Publications Office of the European Union, Luxembourg, pp 81-93 (ISBN 978-92-9213-168-5)

The Federal Government (2008) German Strategy for Adaptation to Climate Change. URL: http://www.bmub.bund.de/fileadmin/bmuimport/files/english/pdf/application/pdf/das_gesamt_en_bf.pdf. Last accessed 25 Aug 2016

Van Den Eeckhaut M, Hervás J (2012) State of the art of national landslide databases in Europe and their potential for assessing landslide susceptibility, hazard and risk. Geomorphology 139140:545-558

World Road Association (2015) International climate change adaptation framework for road infrastructure. PIARC Report 2015R03EN. Authors: Toplis C, Kidnie M, Marchese A, Maruntu C, Murphy H, Sébille R, Thomson S. World Road Association (PIARC), La Défense cedex, France, p 88 (ISBN 978-2-84060-362-7)
Open Access This chapter is licensed under the terms of the Creative Commons Attribution 4.0 International License (http://creativecommons. org/licenses/by/4.0/), which permits use, sharing, adaptation, distribution and reproduction in any medium or format, as long as you give appropriate credit to the original author(s) and the source, provide a link to the Creative Commons license and indicate if changes were made.
The images or other third party material in this chapter are included in the chapter's Creative Commons license, unless indicated otherwise in a credit line to the material. If material is not included in the chapter's Creative Commons license and your intended use is not permitted by statutory regulation or exceeds the permitted use, you will need to obtain permission directly from the copyright holder. 